\title{
ANALYSIS OF THE BLOOD GROUPS OF CHILDREN AND INFANTS.
}

BY

\author{
ELSIE V. CROWE, M.B., Ch.B., Edin.
}

(From the Royal Hospital for Sick (hildren, Edinburgh).

It has long been known that, if the blood of one species of animal is injected into the circulation of another species, the corpuscles of the foreign blood are at once destroyed and their hæmoglobin set free. An analogous hæmolysis may occur when the bloods of certain individuals are mixed with those of other individuals of the same species, and the observation of this fact led to the discovery of blood groups among human beings.

Landsteiner ${ }^{1}$ discovered hæmolysins and iso-hæmolysins twenty-seven years ago. Six years later Jansky² divided human blood into four groups, and showed that the blood of each group had a definite relationship to each of the other three groups. In 1910 Moss $^{3}$ amplified these discoveries and pointed out that the hæmolysis is always preceded by agglutination, and that the interaction between the groups might stop at agglutination.

There are thus two sets of independent reactions between the serum of the one group and the corpuscles of the other, the serum of the one agglutinating or hæmolysing the corpuscles of the other.

First Reaction. The corpuscles of Group I are agglutinated by the sera of Groups II, III and IV; those of Group II are agglutinated by the sera of Groups III and IV ; those of Group III by the sara of Groups II and IV : while those of Group IV are not agglutinated by the serum of any of the other three groups.

Second Reaction. The serum of Group I agglutinates no other corpuscles: that of Group II agglutinates the corpuscles of Groups I and III ; that of Group III agglutinates the corpuscles of Groups I and II ; and the serum of Group IV agglutinates the corpuscles of Groups I, II and III.

These results are set out in Table $I$.

Table I. Interaction of Blood Groups.

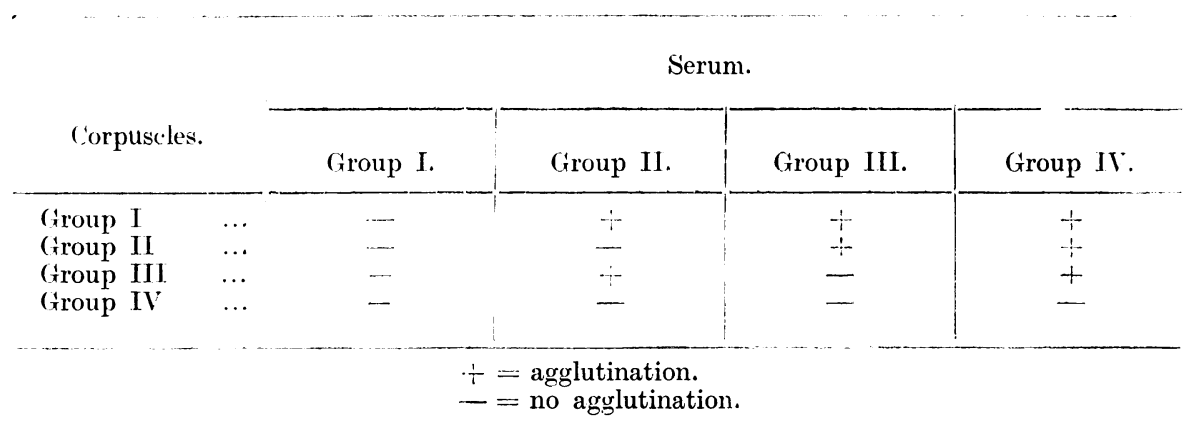

Agglutinins and Iso-agglutinins. The active principles in the serum have been named agglutinin and hæmolysin; and those in the corpuscles iso-agglutinin and iso-hæmolysin. A positive reaction (agglutination or 
hæmolysis) depends on the presence and interaction of these substances in the serum and corpuscles of the two bloods which are being grouped. For example, the serum of Group I lacks agglutinins and the corpuscles of Group IV have no iso-agglutinins (see Table I), therefore the serum of Group I cannot agglutinate the corpuscles of any group, and the corpuscles of Group IV are not agglutinated by the serum of any group : thus individuals belonging to Group I are "universal recipients." and those belonging to Group IV are "universal donors."

\section{Blood Groups of Children.}

It has been stated that an infant has no blood group, and that a baby's blood is compatible with that of its mother. As blood transfusion is so common and successful a form of treatment in burns, surgical shock, marasmus, malæna neonatorum, etc., it is of vital importance to know whether these statements are true or false.

That they are false has been fully proved by Keynes ${ }^{4}$ and Happ ${ }^{5}$. The former grouped a series of newly-born infants, and got many well-marked agglutinations among them, thus proving the existence of definite Groups I, II and III, as the case might be.

In 1920 Happ published the results of his work on blood reactions in children. He found, first, that blood from the umbilical cord often belonged to a different group from that of the maternal blood; and secondly that, although the agglutination reaction of the serum (agglutinins) may not be established until the child is a few months or even two years old, the reaction in the corpuscles (iso-agglutinins) appears before that of the serum, and is of ten present at birth. If the grouping which first appears (at birth) is modified in later life, it is always by the addition of factors-thus a Group IV may develop agglutinins or iso-agglutinins, or both, and so become a Group II or III ; Groups II and III may become Group I, and so on. The reactions. however, are completely established within the first two years of life.

Happ therefore concludes that it is unsafe to transfuse an infant with its mother's blood without first making the usual tests, not only because the child may not belong to the same group as the mother, but also because, although the child's serum may still be without agglutinins, the iso-agglutinins may be already present, and thus transfusion might have serious results if the donor's blood were of an incompatible group.

Keynes has experimentally proved that blood groups are inherited on a definite plan, that of the Mendelian law.

Present Series of Children and Infants.

The following analysis of two hundred children corroborates the investigations of Keynes ${ }^{4}$ and Happ ${ }^{5}$.

The first hundred children examined were all under the age of twelve. They were normal boys and girls suffering from incidental surgical complaints, such as hernia, genuvarum, etc. The second hundred were infants under one year, most of whom were suffering from pneumonia, diarrhœa, vomiting, etc. None had any disease of the blood in which abnormal alteration of blood reactions is known to occur (Keynes). 
The results obtained in both series, children and infants, are shown in Table II, where percentages found in large series of adults are also set out for the sake of comparison. It will be seen that the percentages obtained in both of the present series approximate to those found in adults.

TABLE II. Blood Grovps in Children and Infants.

\begin{tabular}{|c|c|c|c|c|c|}
\hline & & \multicolumn{2}{|c|}{ Author's Series. } & \multirow{2}{*}{$\frac{\text { Moss. }}{1.600 \text { Adults. }}$} & \multirow{2}{*}{$\frac{\text { ('ulpepper. }}{5,000 \text { Adults. }}$} \\
\hline & & 100 Children. & 100 Infants. & & \\
\hline $\begin{array}{l}\text { Group I } \\
\text { Group II } \\
\text { Group III } \\
\text { Group IV }\end{array}$ & $\begin{array}{l}\cdots \\
\cdots \\
\cdots \\
\cdots\end{array}$ & $\begin{array}{r}6 \% \\
39 \% \\
9 \% \\
46 \% \\
6 \%\end{array}$ & $\begin{array}{r}1 \% \\
36 \% \\
6 \% \\
57 \%\end{array}$ & $\begin{array}{r}10 \% \\
40 \% \\
7 \% \\
43 \%\end{array}$ & $\begin{array}{l}3 \% \\
38 \% \\
18 \% \\
+1 \%\end{array}$ \\
\hline
\end{tabular}

\section{Conclusions.}

1. Infants as well as children have a definite blood group.

2. In infants Group I contains a smaller, and Group IV a larger, proportion of cases than in children. This suggests that the blood groups may not be established during the early months of life.

3. Sex and colouring had no apparent relationship to the blood groups.

I am indebted to Prof. John Fraser for the suggestion that I should undertake this investigation, and for granting me facilities in his wards at the Royal Hospital for Sick Children, Edinburgh.

\section{REFERENC'ES'}

1. Landsteiner, K., Wien. Klin. Wchnschr, Vienna, 1901, XI. , 1132.

2. Jansky, J., Klin. Sborink, 1907, VIII, 85.

3. Moss, W. L., Bull. John Hopkins Hosp., Baltimore, 1910, X.XI, (33.

4. Keynes, G., Blood Transfusion, Oxford, 1922, 84, 86.

5. Happ, W. M., J. Exp. Verl., N.Y., 1920, XXXI, 313.

\section{THE BRITISH PADIATRIC ASSOCIATION.}

The first Meeting of the British Pædiatric Association will take place at Windermere on May 4th and 5th. Dr. G. F. Still will preside. For some time the need has been felt for an association which would attract pædiatric physicians from every part of the British Is'es. The rules and conduct of business are based on those of the Association of Physicians. The objects are the advancement of the study of pædiatrics and the promotion of friendship among pædiatricians. The response to the invitations issued has been so unanimous and the list of communications promised for this year so large and interesting, that the success of this first Meeting is assured. It is intended, with the consent of the Association, to publish a hrief résumé of the proceedings in the June number of the "Archives." 